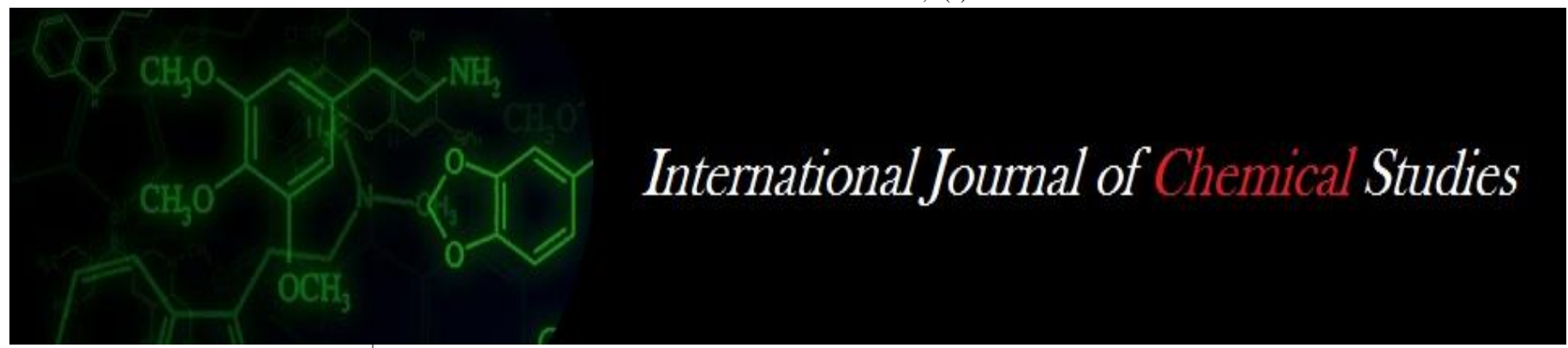

P-ISSN: 2349-8528

E-ISSN: 2321-4902

www.chemijournal.com

IJCS 2020; 8(2): 695-697

(C) 2020 IJCS

Received: 07-01-2020

Accepted: 09-02-2020

Nayan Kishor Adhikary

ICAR-All India Coordinated

Research Project on Sesame and

Niger, Institute of Agricultural

Science, University of Calcutta,

51/2, Hazra Road, Kolkata,

West Bengal, India

\section{Rambilash Mallick}

Department of Agronomy,

Institute of Agricultural Science,

University of Calcutta, 51/2,

Hazra Road, Kolkata,

West Bengal, India
Corresponding Author: Nayan Kishor Adhikary ICAR- All India Coordinated Research Project on Sesame and Niger, Institute of Agricultural Science, University of Calcutta, 51/2, Hazra Road, Kolkata, West Bengal, India

\section{Integrated management of major diseases of sesame (Sesamum indicum L.)}

\section{Nayan Kishor Adhikary and Rambilash Mallick}

\author{
DOI: $\underline{\text { https://doi.org/10.22271/chemi.2020.v8.i2k.8847 }}$
}

\begin{abstract}
Among fungal diseases, stem and root rot, Alternaria leaf spot and Cercospora leaf spot were become major constraints for cultivation of sesame in South 24-Parganas district of West Bengal, India. Considering the fact, the following investigation was carried out for this pathological problem. Field trials conducted on integrated disease management practices to combat major diseases and to increase the seed yield of sesame during summer, 2018 and 2019. Minimum incidence of stem and root rot $(8.8 \%$ and $11.2 \%$ ) with higher yield of $527 \mathrm{~kg} / \mathrm{ha}$ and $577 \mathrm{~kg} / \mathrm{ha}$ were recorded in summer, 2018 and 2019 with application of organic amendment with FYM and neem cake @ $150 \mathrm{~kg} / \mathrm{ha}\left(1: 1, \mathrm{~T}_{4}\right)$. In case of foliar diseases of sesame, applications of FYM + NPK @ 60:30:30 (1:1, T3) was found to be significantly effective by recording minimum incidence of Alternaria leaf spot (6.3\% and 8.4\%) and Cercospora leaf spot $(4.2 \%$ and $5.3 \%)$ coupled with maximum yield $(512 \mathrm{~kg} / \mathrm{ha}$ and $541 \mathrm{~kg} / \mathrm{ha})$ with higher cost benefit (C:B) ratio in summer, 2018 and 2019.
\end{abstract}

Keywords: Incidence, integrated management, leaf spot, rot, sesame

\section{Introduction}

Sesame (Sesamum indicum L.) is an important oilseed crop in India preferred due to edible oil content (about 50\%), nutritious protein (about 23\%) and having sufficient carbohydrate (15\%) (Ranganatha et al., 2012) ${ }^{[1]}$. India is the fifth largest vegetable oil economy in the world, next only to USA, China, Brazil and Argentina and has an annual turnover of about Rs. 80,000 crore. India accounts for $12-15 \%$ of oilseeds area, $7-8 \%$ of oilseeds production, $6-7 \%$ of vegetable oils production, $9-12 \%$ of vegetable oils import and $9-10 \%$ of edible oils consumption (Jha et al., 2014) ${ }^{[2]}$. Among the oilseed crops, sesame ranks first for its higher oil content with $6335 \mathrm{kcal} \mathrm{kg}^{-1}$ of dietary energy in seeds (Kumar and Goel, 1994) ${ }^{\text {[3]. Due to }}$ intensive cultivation practices the crop has been found to suffer from various diseases. About 72 fungi, 7 bacteria, 1 phytoplasmal and 1 viral disease have been reported from India (Vyas et al., 1984) ${ }^{[4]}$. Out of these, about 32 diseases (14 major and 18 minor) occur in India.

Sesame cultivated in summer season in the South 24-Parganas district of West Bengal is affected by root rot, Alternaria leaf blight and Cercospora leaf blight diseases resulting in low productivity. Root rot of sesame caused by Macrophomina phaseolina (Tassi) Goid a pycnidia producing fungus is one of the most important soil inhabiting pathogen, attacks a large number of host plants including oilseeds, pulses, vegetables and ornamentals (Shaw, 1912; Pearl, 1923; Park, 1927; Likhite, 1936; Thirumalachar, 1953; Zak, 1971; Grower and Shakhuja, 1981; Gangopadhay et al., 1982) [5, 6, 7, 8, 9, 10,11,12]. Macrophomina phaseolina as very serious and destructive pathogen in all sesame growing areas and causes 5-100\% yield loss (Vyas, 1981) ${ }^{[13]}$. Other researchers estimated yield loss of around $57 \%$ at about $40 \%$ of disease incidence (Maiti el al., 1988) ${ }^{[14]}$. However, information is lacking particularly in South 24 Parganas district of West Bengal for management of these diseases in sesame. Keeping in view, the present investigation was undertaken to find the potential of IDM practices to manage these diseases.

\section{Materials and Methods}

A field trial was conducted at Agricultural Experimental Farm, Institute of Agricultural Science, University of Calcutta, Baruipur, South 24 Parganas during two consecutive summer seasons, 2018 and 2019. The experiment was laid out in randomized block design with five 
treatments in integrated manner, viz. T 1 NPK @ 60:30:30; T NPK @ 40:20:20; T $:$ FYM + NPK @ 60:30:30 (1:1); T4: Organic amendment with FYM and neem cake @ $150 \mathrm{Kg} / \mathrm{ha}$ (1:1); $\mathrm{T}_{5}$ : Untreated check (control) infour replications using the local variety, savitri. The incidence of Macrophomina root rot was recorded individually by counting the number of affected and healthy plants at random quadrate selection in each plot and the percent incidence was calculated. Per-cent disease incidence (PDI) was worked outforAlternaria leaf spotand Cercospora leaf spot of sesame.The grain yield was recorded and cost benefit $(\mathrm{C}: \mathrm{B})$ ratio was worked out. The statistical analysis of the experimental data was carried out by adopting the standard method as described by Gomez and Gomez (1984) ${ }^{[15]}$.

\section{Results and Discussion}

Totally five treatments were tested, among themthe minimum root rot incidence $(8.8 \%)$ with maximum seed yield (527 $\mathrm{kg} / \mathrm{ha}$ ) and $\mathrm{C}: \mathrm{B}$ ratio was recorded in the treatment of $\mathrm{T} 4$ (organic amendment with FYM and neem cake @ 150kg/ha) followed by root rot incidence $(15.1 \%)$ with $512 \mathrm{~kg} / \mathrm{ha}$ higher yield was recorded in T3 (FYM + N:P:K @ 60:30:30, 1:1) in summer, 2018 (Table 1). On the other hand, the minimum root rot incidence $(11.2 \%)$ with maximum yield $(577 \mathrm{~kg} / \mathrm{ha})$ was recorded in the treatment of T4 (organic amendment with FYM and neem cake @ 150kg/ha) followed by root rot incidence $15.1 \%$ with $541 \mathrm{~kg} / \mathrm{ha}$ higher seed yield was recorded in T3 (FYM+N:P:K @ 60:30:30, 1:1) in summer, 2019 (Table 2). The present investigation is in line with the report of Adhikary et al., (2019) ${ }^{[16]}$. Addition of neem cake promotes biological activity in soil by providing nutrients and favorable conditions for the antagonists besides enhancing host growth and vigor was documented by Mallesh et al. (2008) ${ }^{[17]}$.

Table 1: Integrated management of major diseases of sesame during summer, 2018.

\begin{tabular}{|c|c|c|c|c|c|}
\hline Treatment & Root rot $(\%)$ & Alternaria leaf spot (\%) & Cercospora leaf spot (\%) & Yield (kg/ha) & B:C ratio \\
\hline T1:NPK@60:30:30 & $\begin{array}{c}17.2 \\
(24.9)\end{array}$ & \begin{tabular}{|c|}
14.4 \\
$(22.6)$
\end{tabular} & $\begin{array}{c}11.2 \\
(19.9)\end{array}$ & 483 & 2.10 \\
\hline T2:NPK @ 40:20:20 & $\begin{array}{c}21.4 \\
(27.9)\end{array}$ & $\begin{array}{c}10.9 \\
(19.7)\end{array}$ & $\begin{array}{c}13.3 \\
(21.8)\end{array}$ & 439 & 1.94 \\
\hline T3:FYM + NPK @ 60:30:30 (1:1) & $\begin{array}{c}15.1 \\
(23.2)\end{array}$ & $\begin{array}{c}6.3 \\
(14.9)\end{array}$ & $\begin{array}{c}4.2 \\
(12.1)\end{array}$ & 512 & 2.21 \\
\hline $\begin{array}{l}\text { T4: Organic amendment with FYM } \\
\text { and Neem cake @ } 150 \mathrm{Kg} / \mathrm{ha}(1: 1)\end{array}$ & $\begin{array}{c}8.8 \\
(17.6) \\
\end{array}$ & $\begin{array}{c}7.7 \\
(16.0) \\
\end{array}$ & $\begin{array}{c}6.7 \\
(15.2) \\
\end{array}$ & 527 & 2.34 \\
\hline T5: Untreated check & $\begin{array}{c}26.3 \\
(31.2)\end{array}$ & $\begin{array}{c}22.1 \\
(28.4)\end{array}$ & $\begin{array}{c}16.8 \\
(24.6)\end{array}$ & 343 & 1.53 \\
\hline S.Em \pm & 1.01 & 1.74 & 1.35 & 4.33 & \\
\hline $\mathrm{CD}(5 \%)$ & 3.30 & 5.69 & 4.40 & 14.11 & \\
\hline
\end{tabular}

*Figures in parenthesis are angular transformed values

Table 2: Integrated management of major diseases of sesame during summer, 2018.

\begin{tabular}{|c|c|c|c|c|c|}
\hline Treatment & Root rot $(\%)$ & Alternaria leaf spot (\%) & Cercospora leaf spot (\%) & Yield (kg/ha) & C:B ratio \\
\hline T1: NPK @ 60:30:30 & $\begin{array}{c}20.7 \\
(27.39)\end{array}$ & $\begin{array}{c}14.4 \\
(22.64)\end{array}$ & $\begin{array}{c}15.1 \\
(23.22)\end{array}$ & 501 & 2.17 \\
\hline $\mathrm{T}_{2}:$ NPK @ 40:20:20 & $\begin{array}{c}22.5 \\
(28.58) \\
\end{array}$ & $\begin{array}{c}9.1 \\
(18.03) \\
\end{array}$ & $\begin{array}{c}14.7 \\
(22.92)\end{array}$ & 474 & 1.92 \\
\hline $\mathrm{T}_{3}: \mathrm{FYM}+\mathrm{NPK} @ 60: 30: 30(1: 1)$ & $\begin{array}{c}15.1 \\
(23.21)\end{array}$ & $\begin{array}{c}8.4 \\
(17.30)\end{array}$ & $\begin{array}{c}5.3 \\
(13.85)\end{array}$ & 541 & 2.22 \\
\hline $\begin{array}{c}\mathrm{T}_{4}: \text { Organic amendment with FYM and } \\
\text { Neem cake @ } 150 \mathrm{Kg} / \mathrm{ha}(1: 1)\end{array}$ & $\begin{array}{c}11.2 \\
(20.00)\end{array}$ & $\begin{array}{c}12.6 \\
(21.24)\end{array}$ & $\begin{array}{c}9.1 \\
(18.03)\end{array}$ & 577 & 2.29 \\
\hline $\mathrm{T}_{5}$ : Untreated check & $\begin{array}{c}28.8 \\
(32.73)\end{array}$ & $\begin{array}{c}22.5 \\
(28.60)\end{array}$ & $\begin{array}{c}18.9 \\
(26.10)\end{array}$ & 419 & 1.75 \\
\hline S.Em+ & 0.91 & 1.04 & 1.23 & 6.66 & \\
\hline $\mathrm{CD}(5 \%)$ & 2.97 & 3.40 & 4.03 & 21.74 & \\
\hline
\end{tabular}

*Figures in parenthesis are angular transformed values

\section{Conclusion}

In the present investigation, among five different treatments in integrated management practices, soil application of organic amendment with FYM and neem cake @ $150 \mathrm{~kg} / \mathrm{ha}$ (1:1) and FYM + NPK @ 60:30:30 (1:1) were observed to be superior over other treatment in management of stem and root rot. In case of both foliar diseases of Alternaria leaf spot and Cercospora leaf spot, soil applications of FYM + NPK @ 60:30:30 (1:1) was quite effective. Such information will be helpful in formulation of integrated management schedule for the management of these diseases in sesame.

\section{References}

1. Ranganatha ARG, Lokesha, R, Tripnthi A, Asafa, T, Paroha, S. Srivastava, MK. Sesame improvement present status and future strategies. Journal of Oilseeds Research. 2012; 29(1): 1-26.

2. Jha G, Pal S, Mathur VC, Bisaria G, Dubey SK. Edible oilseed supply and demands scenario in India: Implication of policy, Div. Agric. Economics, IARI, New Delhi, 2014.

3. Kumar S, Goel PD. A great ancient oilseed sesamum. Farmers and Parliament. 1994; 12: 6-7.

4. Vyas SC, Prasad KVV, Khare MN. Diseases of sesamum and niger in India and their control. Department of Plant Pathology, JNKVV, Jabalpur, M. P. Bull., 1984, 16.

5. Shaw, FJF. The morphology and parasitism of Rhizoctonia. Memoir department of Agriculture Botany Series, 1912; 4: 116-153.

6. Pearl RT. Report of the Mycologist to the Government of the Central Provinces and Berer. Report of department of 
Agriculture Central Provinces and Berar, for the year ending $30^{\text {th }}$ June, 1922, 1923, 19-20

7. Park M. Mycological studies on the occurrence of Rhizoctonia bataticola (Taub.) Butler on coconut. Tropical Agriculturist. 1927; 69: 7-8.

8. Likhite VN. Host range of Gujarat cotton root rot. Proceedings of the Association of Economic Biologists, Coimbatore, 1936; 3: 18-20.

9. Thirumalachar MJ. Pycnidial stage of charcoal rot inciting fungus with a discussion on its nomenclature. Phytopathology. 1953; 43: 608-610.

10. Zak B. The morphology and parasitism of Rhizoctonia. Canadian Journal of Botany. 1971; 49: 1079-1084.

11. Grower RK, Shakhuja PK. Some pathological studies on Rhizoctonia bataticola leaf blight of mungbean. Indian Phytopathology. 1981; 34: 24-29.

12. Gangopadhyay S, Wyllie TD, Teaque WR. Effect of bulk density andmoisture content of soil on the survival of Macrophomina phaseolina. Plant and Soil. 1982; 68: 241-247.

13. Vyas SC. Diseases in sesamum in India and their control. Pesticides. 1981; 15:10.

14. Maiti S, Hegde MR, Chattopadhyay SB. Handbook of Annual Oilseed Crops. Oxford and IBH Publ. Co. Pvt. Ltd., New Delhi, 1988.

15. Gomez KA, Gomez AA. Statistical procedures for Agricultural Research. John Wiley and Sons, New York, 1984, 680.

16. Adhikary NK, Chowdhury R, Begum T, Mallick R. Integrated Management of Stem and Root Rot of Sesame (Sesamum indicum L.) caused by Macrophomina phaseolina (Tassi) Goid. International Journal of Current Microbiology and Applied Sciences. 2019; 8(4): 804808.

17. Mallesh SB, Narendrappa T, Ramanujam, B. Evaluation of microbial antagonists and organic amendments on root rot of sage (Salvia officinalis) by Fusarium solani and Rhizoctonia solani. Karnataka Journal of Agricultural Sciences. 2008; 21(2): 301-302. 